\title{
Segmental variability of glucocorticoid induced electrolyte transport in rat colon
}

\author{
G I Sandle
}

\begin{abstract}
Recent studies suggest that the ability of glucocorticoids to reduce diarrhoea in active colitis may reflect their direct effects on distal colonic electrogenic $\mathrm{Na}^{+}$transport and water absorption, as well as their anti-inflammatory action. To determine whether glucocorticoids induce similar changes in proximal colon, specific $\mathrm{Na}^{+}$ and $\mathrm{K}^{+}$channel blockers (amiloride and tetraethylammonium chloride (TEA) respectively) were used to evaluate the cation transport properties of rat proximal and distal colon in vitro after three days treatment with the glucocorticoid agonist dexamethasone $(600 \mu \mathrm{g} / 100$ g/day). In the proximal colon, dexamethasone increased short circuit current (Isc) 2.3 fold $(p<0.025)$ and total conductance $\left(G_{,}\right)$by $87 \%$ $(p<0.015)$, but had negligible effects on the maximum activity of the basolateral membrane $\mathrm{Na}^{+}-\mathrm{K}^{+}$pump and the baseline $\mathrm{Na}^{+}$and $\mathrm{K}^{+}$ conductive properties of the apical membrane. Additional studies with diphenylamine-2carboxylic acid (a $\mathrm{Cl}^{-}$channel blocker) suggested that the dexamethasone induced increases in Isc and $G_{\mathbf{t}}$ in proximal colon reflected stimulation of an electrogenic $\mathrm{Cl}^{-}$ secretory process. In contrast, in the distal colon dexamethasone increased Isc 10 fold $(p<0.025), G_{\text {, by }} 100 \%(p<0.015)$, and the maximum activity of the basolateral $\mathrm{Na}^{+}-\mathrm{K}^{+}$ pump by $200 \%(\mathbf{p}<0.05)$, and induced substantial $\mathrm{Na}^{+}$and $\mathrm{K}^{+}$conductances in the apical membrane. These results indicate that dexamethasone stimulates electrogenic $\mathrm{Na}^{+}$transport and water absorption to a significant degree only in the distal segment of rat colon. Thus in patients with active colitis, that part of the antidiarrhoeal action of glucocorticoids that reflects stimulation of electrogenic $\mathrm{Na}^{+}$ transport (and hence water absorption) may be restricted to the descending colon and rectum.
\end{abstract}

Oral or intravenous glucocorticoid agonists form the cornerstone of treatment in patients with acute inflammatory disease of the large bowel. ${ }^{1-3}$ Until recently the efficacy of glucocorticoids was assumed to reflect their well known anti-inflammatory effects but it is now clear that pharmacological doses of glucocorticoids administered parenterally enhance rectal sodium $\left(\mathrm{Na}^{+}\right)$ and water absorption to the same extent in patients with active ulcerative colitis and in normal subjects. ${ }^{4}$ It is also apparent that the predominant mechanism for $\mathrm{Na}^{+}$absorption in human distal colon and rectum is electrogenic, ${ }^{56}$ and stimulated by both mineralocorticoid and glucocorticoid agonists. ${ }^{47}$ These observations suggest that glucocorticoids (which at high doses bind substantially to mineralocorticoid receptors within colonic mucosa $a^{8}$, reduce diarrhoea in active colitis by stimulating distal colonic $\mathrm{Na}^{+}$ and water absorption as well as by suppressing the underlying inflammatory process. It remains unclear, however, whether glucocorticoids also stimulate electrogenic $\mathrm{Na}^{+}$and water absorption in human proximal colon.

The assessment of glucocorticoid induced electrolyte transport in different segments of human colon in vivo poses a number of technical problems and would provide little information about changes in the biophysical properties of the colonic mucosa. The present study was therefore designed to determine the effects of long term dexamethasone treatment on the cell membrane barriers and forces controlling $\mathrm{Na}^{+}$and $\mathrm{K}^{+}$ transport in rat proximal and distal colon. The results indicate that pharmacological doses of this glucocorticoid agonist induce changes in the properties of epithelial cell membranes consistent with the stimulation of electrogenic $\mathrm{Na}^{+}$ absorption and $\mathrm{K}^{+}$secretion in the distal but not in the proximal colonic segment.

\section{Methods}

Experiments were performed in non-fasting male Sprague-Dawley rats weighting 250-300 g. Control animals were fed $2 \sigma^{\circ} \mathrm{g}$ day of normal rat chow containing $2 \cdot 8 \mathrm{mmol} \mathrm{Na}{ }^{+}$. Glucocorticoid treated animals were fed normal rat chow and injected intraperitoneally with $600 \mu \mathrm{g} / 100 \mathrm{~g} /$ day of dexamethasone for three days. Dexamethasone was used because its effects on the ion transport and electrical properties of rat distal colon have previously been studied in detail. ${ }^{910}$ All animals were allowed tap water to drink ad libitum. Animals were killed by cervical dislocation, those in the glucocorticoid treated group being killed 24 hours after the final injection of dexamethasone. The colon was rinsed with $\mathrm{NaCl}$ Ringer solution containing (in $\mathrm{mmol} / \mathrm{l}): \mathrm{Na}^{+} 136 \cdot 2 ; \mathrm{K}^{+} 7 \cdot 0 ; \mathrm{Cl}^{-} 121 ; \mathrm{Ca}^{2+} 2 \cdot 0 ;$ $\mathrm{Mg}^{2+} 1 \cdot 2 ; \mathrm{HCO}_{3}^{-} 25 ; \mathrm{H}_{2} \mathrm{PO}_{4}^{-} 1 \cdot 2 ; \mathrm{SO}_{4}^{2+} 1 \cdot 2$; and glucose $11 \cdot 1$ and was maintained at $37^{\circ} \mathrm{C}$ and $\mathrm{pH}$ $7 \cdot 4$ by gassing with a $95 \% \mathrm{O}_{2}: 5 \% \mathrm{CO}_{2}$ mixture.

The colon was stripped of serosa and muscle layers, and a $2 \mathrm{~cm}$ piece of distal colon (that segment beginning $4 \mathrm{~cm}$ from the anus) or proximal colon (that segment immediately adjacent to the caecum) was mounted in an Ussing type chamber modified to eliminate tissue edge damage." Tissue area was $1 \mathrm{~cm}^{2}$. Tissues were bathed on both sides with $12 \mathrm{ml} \mathrm{NaCl}$ Ringer solution and were temperature and $\mathrm{pH}$ regulated as described above. Electrical measurements were obtained under open circuit conditions. Transepithelial voltage $\left(\mathrm{V}_{1}\right)$ was monitored continuously with salt bridges (4\% agar in 0.5 $\mathrm{mol} / \mathrm{l} \mathrm{KCl}$ ) placed on either side of the tissue and 
connected to a voltmeter via balanced calomel half cells. Using Ohm's law, total tissue conductance $\left(G_{1}\right)$ was calculated from the increase in $V_{t}$ that occurred in response to a rectangular current pulse $\left(120 \mu \mathrm{A} / \mathrm{cm}^{2}, 2.5\right.$ seconds duration $)$ applied across the mucosa via an Anapulse stimulator (WPI, New Haven, CT, USA). The equivalent short circuit current (Isc) was calculated as Isc $=V_{1} \cdot G_{1}$.

Baseline electrical measurements were obtained after 20-25 minutes when $V_{\text {, }}$ and $G_{t}$ were stable. Effects of the $\mathrm{Na}^{+}$channel blocker amiloride (final concentration $0.1 \mathrm{mmol} / \mathrm{l}$ ) and the $\mathrm{K}^{+}$channel blocker tetraethylammonium chloride (TEA; final concentration $30 \mathrm{mmol} / \mathrm{l}$ ) were determined by adding the drugs sequentially to the mucosal solution. Electrical measurements were made five minutes after the amiloride and TEA (in the presence of amiloride) had been added when $V_{t}$ and $G_{t}$ were stable.

Dexamethasone treatment stimulated an amiloride insensitive increase in Isc in the proximal colon (see Results) which suggested that the glucocorticoid induced an electrogenic anion secretory process in this segment. Similar changes were not observed, however, in the distal colon. To study this further, tissues were bathed in $\mathrm{NaCl}$ Ringer solution and $0.1 \mathrm{mmol} / \mathrm{l}$ amiloride was added to the mucosal solution to inhibit any component of Isc which may have reflected electrogenic $\mathrm{Na}^{+}$transport. The $\mathrm{Cl}^{-}$ conductive properties of the apical membrane were then evaluated by measuring changes in Isc produced by adding the $\mathrm{Cl}^{-}$channel blocker diphenylamine-2-carboxylic acid (final concentration $2.5 \mathrm{mmol} / \mathrm{l}$ ) to the mucosal solution.

Basolateral $\mathrm{Na}^{+}-\mathrm{K}^{+}$pump activity was assessed as described previously. ${ }^{12}$ Tissues were bathed on both sides in a high $\mathrm{K}^{+}, \mathrm{Na}^{+}$and $\mathrm{Cl}^{-}$free solution containing (in mmol/l): $\mathrm{K}^{+} 140 ; \mathrm{HCO}_{3}{ }^{-} 25 ; \mathrm{Ca}^{2+}$ 10 (methane sulphonate); $\mathrm{Mg}^{2+} 1 \cdot 2 ; \mathrm{H}_{2} \mathrm{PO}_{4}^{-} 1 \cdot 2$; $\mathrm{MeSO}_{3}{ }^{-}$20; gluconate 113.8; and glucose $11 \cdot 1$. Nystatin was added to the mucosal solution (final concentration $960 \mathrm{U} / \mathrm{ml}$ ) to render the apical membrane freely permeable to monovalent ions, ${ }^{13}$ and under these conditions $V_{t}$ and Isc were zero. Amiloride $(0.1 \mathrm{mmol} / \mathrm{l})$ was added to the mucosal solution to block native $\mathrm{Na}^{+}$channels, and the $\mathrm{Na}^{+}$concentration of the serosal and then the mucosal solution raised in $10 \mathrm{mmol} / \mathrm{l}$ increments (using a stock $\mathrm{Na}^{+}$gluconate solution), to a final concentration of $50 \mathrm{mmol} / 1$. Serosal addition of $\mathrm{Na}^{+}$had no effect, but increasing the mucosal (and intracellular) $\mathrm{Na}^{+}$concentration increased $V_{1}$ and Isc to stable values after two to

TABLE I Baseline electrical measurements in proximal and distal colon from control and dexamethasone treated animals (values mean (SEM))

\begin{tabular}{|c|c|c|c|}
\hline & $\begin{array}{l}V_{i} \\
(m V)\end{array}$ & $\begin{array}{l}G \\
\left(m S / \mathrm{cm}^{2}\right)\end{array}$ & $\begin{array}{l}I s c \\
\left(\mu A / c^{2}\right)\end{array}$ \\
\hline $\begin{array}{l}\text { Proximal colon: } \\
\text { Control rats }(n=10) \\
\text { Dexamethasone treated rats }(n=10)\end{array}$ & $\begin{array}{l}-2.5(0.4) \\
-3.4(0.7) \\
\text { NS }\end{array}$ & $\begin{array}{l}19 \cdot 3(3.4) \\
36 \cdot 1(5 \cdot 8) \\
<0.015\end{array}$ & $\begin{array}{l}45(12) \\
103(18) \\
<0.025\end{array}$ \\
\hline $\begin{array}{l}\text { Distal colon: } \\
\text { Control rats }(\mathrm{n}=12) \\
\text { Dexamethasone treated rats }(\mathrm{n}=9) \\
\mathrm{p}^{\star \star}\end{array}$ & $\begin{array}{l}-7 \cdot 3(0 \cdot 8)^{\star} \\
-33 \cdot 0(1 \cdot 3) \\
<0 \cdot 01\end{array}$ & $\begin{array}{c}8 \cdot 8(0 \cdot 8)^{\star} \\
17 \cdot 7(2 \cdot 6) \\
<0 \cdot 015\end{array}$ & $\begin{array}{c}62(8) \\
618(130) \\
<0.0025\end{array}$ \\
\hline
\end{tabular}

$\mathrm{V}_{\mathrm{t}}=$ transepithelial voltage (negative with respect to serosal solution); $\mathrm{G}_{\mathbf{1}}=$ total conductance; Is $=$ calculated short circut current; $n=$ number of tissues studied. $\star=<0.05$ compared with proximal colon from control animals.

$\star \star=$ difference between control and dexamethasone treated tissues. three minutes. Pump activity was evaluated from the increases in Isc measured at increasing mucosal $\mathrm{Na}^{+}$concentrations, using an iterative least squares routine to fit the data to a mathematical model describing the highly cooperative binding of $\mathrm{Na}^{+}$to $\mathrm{Na}^{+}-\mathrm{K}^{+}$pump sites. ${ }^{14}$ This model yields several kinetic parameters: Isc,max =apparent maximum short circuit current, $\mathrm{K}_{\mathrm{Na}}=\mathrm{Na}^{+}$concentration at which the slope of Isc on $\mathrm{Na}^{+}$concentration is maximal, and $n$ (Hill coefficient $)=$ the minimum number of $\mathrm{Na}^{+}$ions binding to each $\mathrm{Na}^{+}-\mathrm{K}^{+}$pump site.

Student's $t$ test (two tailed) was used to make statistical comparisons between groups (nonpaired test), and to assess the significance of the changes induced by amiloride and TEA (paired test).

\section{Results}

EFFECTS OF DEXAMETHASONE ON BASELINE ELECTRICAL PROPERTIES

The basal electrical properties of proximal and distal colon from control and dexamethasone treated animals are summarised in Table $I$.

In control animals, Isc was similar in the

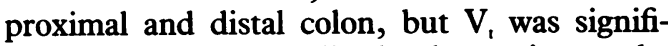
cantly greater in the distal colon owing to the lower electrical conductance $\left(G_{\mathbf{t}}\right)$ in this segment. In the proximal colon, dexamethasone increased Isc and $G$, by $129 \%$ and $87 \%$ respectively above control values, while $V_{\text {, was }}$ unchanged. In contrast, in the distal colon dexamethasone increased Isc 10 fold and $G$, by $100 \%$, resulting in a 4.5 fold increase in $V$, above the control value. Thus, while dexamethasone increased $G$ in the proximal and distal colon, stimulation of Isc (and $V_{1}$ ) was far more pronounced in the distal segment.

\section{EFFECTS OF AMILORIDE AND TEA}

The effects of amiloride and TEA in proximal and distal colon from control and dexamethasone treated animals are shown in Figure 1.

In proximal colon from control animals, the mucosal addition of amiloride and TEA had no effect on $V_{1}, G_{1}$ or Isc, indicating that apical $\mathrm{Na}^{+}$and $\mathrm{K}^{+}$conductances were negligible or absent.

In proximal colon from dexamethasone treated

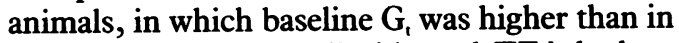
controls (Table I), amiloride and TEA had no effect on $V_{t}, G_{1}$ or Isc (Fig 1 ), which suggests that the dexamethasone stimulated rise in baseline $G_{\text {, }}$ in this segment reflected the induction of a conductive pathway for ions other than $\mathrm{Na}^{+}$and $\mathbf{K}^{+}$.

In distal colon from control animals, amiloride produced small decreases in $\mathrm{V}_{1}(2.6 \mathrm{mV}$, $\mathrm{p}<0.05$ ) but no change in $\mathrm{G}_{\mathrm{t}}$ or Isc, and TEA was without effect. These results indicate that in this group of tissues, apical cation conductances were relatively small (in the case of $\mathrm{Na}^{+}$) or absent (in the case of $\mathrm{K}^{+}$).

In contrast to the other three groups, amiloride and TEA produced noticeable changes in the electrical properties of distal colon from dexamethasone treated animals. The addition of 


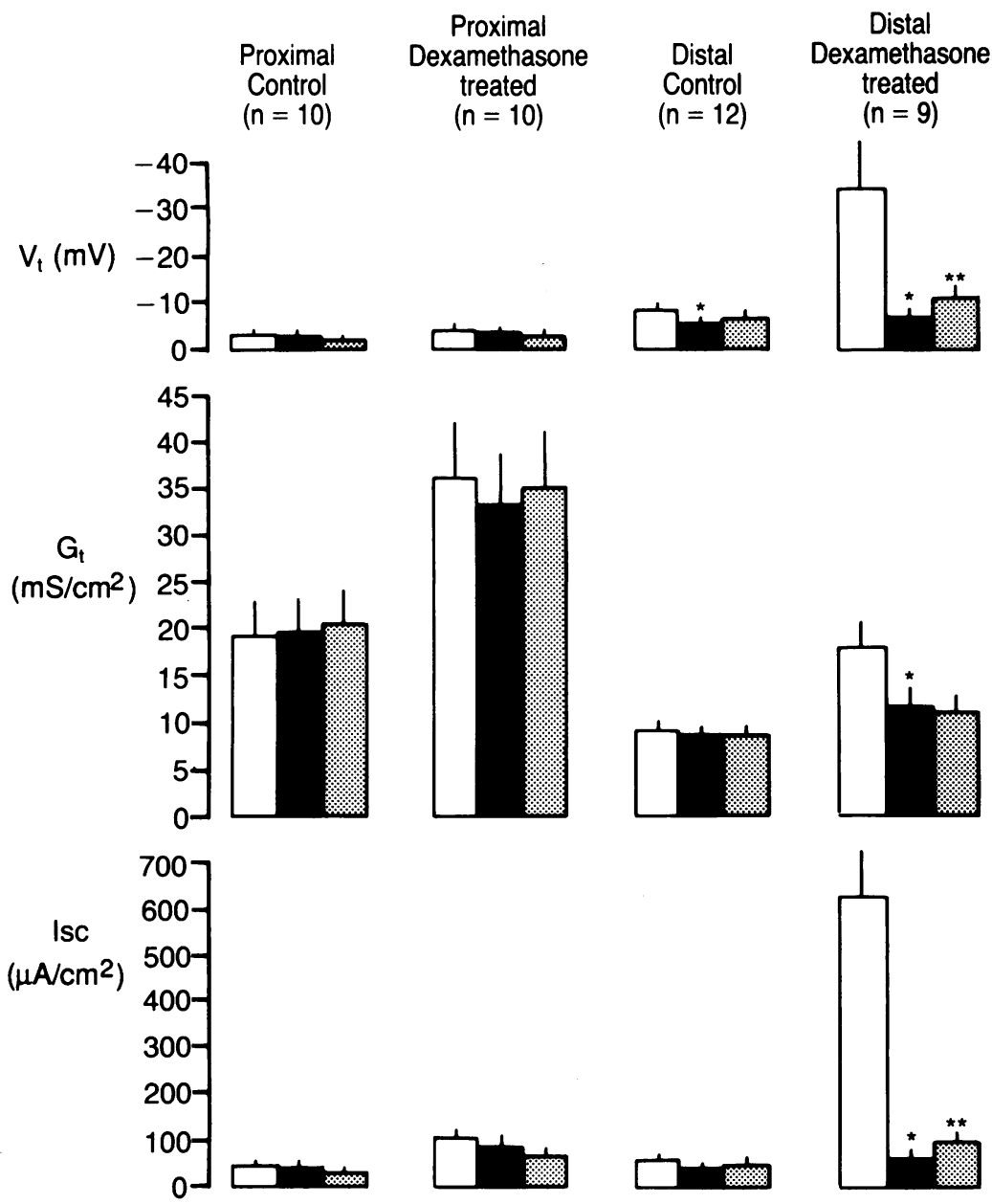

Figure 1: Effects of amiloride ( $0.1 \mathrm{mmol} / \mathrm{l})$ and tetraethylammonium chloride (TEA, 30 mmolll) on transepithelial measurements in proximal and distal colon from control and dexamethasone treated animals. Mean (SEM) values presented are those under baseline conditions (open bars), in the presence of amiloride (filled bars), and in the presence of amiloride plus TEA (stippled bars). $V, G$, and Isc are defined in footnote to Table I. ${ }^{\star} p<0.05$ compared with basal or pre-amiloride value; ${ }^{\star \star} p<0.05$ compared with value in the presence of amiloride alone (Bonferroni correction applied to $p$ values). $n=$ number of tissues studied. amiloride decreased $\mathrm{V}$, by $27 \cdot 3 \mathrm{mV}(\mathrm{p}<0 \cdot 05)$, which reflected appreciable decreases in Isc (561 $\left.\mu \mathrm{A} / \mathrm{cm}^{2}, \mathrm{p}<0.05\right)$ and $\mathrm{G}_{\mathrm{t}}\left(6.5 \mathrm{mS} / \mathrm{cm}^{2}, \mathrm{p}<0.05\right)$. These changes indicate that amiloride blocked a substantial apical $\mathrm{Na}^{+}$conductive pathway, and thereby inhibited the electrogenic $\mathrm{Na}^{+}$transport process induced by dexamethasone. The subsequent addition of TEA increased Isc (by $37 \mu \mathrm{A}$ / $\mathrm{cm}^{2}, \mathrm{p}<0.025$ ), and $\mathrm{V}_{\mathrm{t}}$ (by $4.4 \mathrm{mV}, \mathrm{p}<0.025$ ), changes consistent with the blockade of a dexamethasone induced apical $\mathrm{K}^{+}$conductive pathway.

TABLE II Effects of diphenylamine-2-carboxylic acid (DPC) on amiloride insensitive calculated short circuit current (Isc) in proximal and distal colon from control and dexamethasone treated animals (values mean (SEM))

\begin{tabular}{lccc}
\hline & $\begin{array}{l}I s c\left(\mu A / \mathrm{cm}^{2}\right) \\
\text { pre-DPC }\end{array}$ & $\begin{array}{l}I s c\left(\mu \mathrm{A} / \mathrm{cm},{ }^{2}\right) \\
\text { post-DPC }\end{array}$ & $p$ \\
\hline Proximal colon: & & & \\
$\quad$ Control rats $(\mathrm{n}=4)$ & $74(12)$ & $9(7)$ & $<0.05$ \\
$\quad$ Dexamethasone treated rats $(\mathrm{n}=7)$ & $139(16)$ & $3(2)$ & $<0.0001$ \\
Distal colon: & $22(3)$ & $6(2)$ & $<0.025$ \\
$\quad$ Control rats $(\mathrm{n}=4)$ & $30(6)$ & $14(1)$ & 0.06 \\
Dexamethasone treated rats $(\mathrm{n}=5)$ & & & \\
\hline
\end{tabular}

$\mathrm{n}=$ number of tissues studied. Steady state measurements of Isc were obtained with tissues bathed in $\mathrm{NaCl}$ Ringer solution (in the presence of $0.1 \mathrm{mmol} / \mathrm{l}$ mucosal amiloride) before and after the addition of $2.5 \mathrm{mmol} / \mathrm{l}$ DPC to the mucosal side.
EFFECTS OF DIPHENYLAMINE-2-CARBOXYLIC ACID (DPC)

Bathed in $\mathrm{NaCl}$ Ringer solution, proximal and distal colonic segments from control animals generally show a variable but modest Isc which may reflect, at least in part, the $\mathrm{Cl}^{-}$secretory tone of the tissues, as Isc decreases when $\mathrm{Cl}^{-}$is replaced with gluconate. ${ }^{15}$ Dexamethasone produced an amiloride and TEA insensitive increase in Isc in the proximal colon (Table I and Fig 1), consistent with the stimulation of an electrogenic $\mathrm{Cl}^{-}$secretory process. The effects of the $\mathrm{Cl}^{-}$ channel blocker DPC on the amiloride insensitive component of Isc were therefore studied in proximal and distal colon from control and dexamethasone treated animals, and the results are summarised in Table II.

In distal colon from control and dexamethasone treated animals, and proximal colon from control animals, DPC produced relatively modest decreases in amiloride insensitive Isc, consistent with the blockade of a small native apical $\mathrm{Cl}^{-}$ conductance in each of these three groups. In contrast, the high amiloride insensitive Isc in proximal colon from dexamethasone treated animals (mean 139 (SEM) (16) $\mu \mathrm{A} / \mathrm{cm}^{2}$ ) was abolished by DPC, which suggests that dexamethasone induced a substantial apical $\mathrm{Cl}^{-}$ conductance in the proximal segment.

\section{EFFECTS OF DEXAMETHASONE ON THE}

BASOLATERAL $\mathrm{Na}^{+}-\mathrm{K}^{+}$PUMP

Figure 2 shows the changes in Isc that occurred in response to $10 \mathrm{mmol} / \mathrm{l}$ increases in the mucosal $\mathrm{Na}^{+}$concentration in colonic segments from control and dexamethasone treated animals. The kinetic parameters derived from the best fit curves (Fig 2) are summarised in Table III. In the proximal colon, Isc at each concentration of $\mathrm{Na}^{+}$ tended to be greater in the dexamethasone treated than in the control animals, although these differences were not significant, and Isc, $\max , \mathrm{K}_{\mathrm{Na}}$, and $n$ were similar in the two groups. In the distal colon, however, Isc at each concentration of $\mathrm{Na}^{+}$was two to three times greater in the dexamethasone treated than in the control animals $(p<0.05)$, and Isc, max was increased

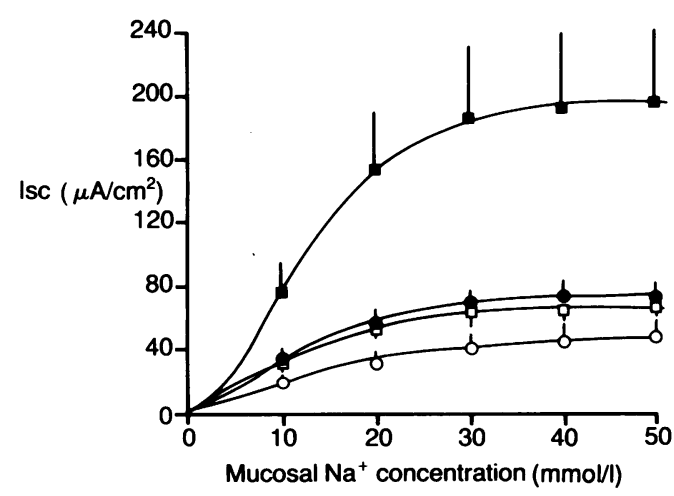

Figure 2: Response of short circuit current (Isc) to increasing mucosal concentrations of $\mathrm{Na}^{+}$in control $(\mathrm{O}-\mathrm{O}, n=5)$ and dexamethasone-treated $(-, n=7)$ proximal colon, and control $(\square-\square, n=6$ ) and dexamethasone-treated ( $\square-\square$, $n=8$ ) distal colon. Each point represents the mean (SEM) of the data at each concentration of $\mathrm{Na}^{+}$and the curves are best fits as described by the model of highly cooperative binding (see Methods). Best fit values for the curves are presented in Table III. 
TABLE III Kinetics of the basolateral $\mathrm{Na}^{+}-\mathrm{K}^{+}$pump in proximal and distal colon from control and dexamethasone treated animals (values mean (SEM))

\begin{tabular}{lcll}
\hline & $\begin{array}{l}I s c, \max \\
\left(\mu \mathrm{A} / \mathrm{cm}^{2}\right)\end{array}$ & $\begin{array}{l}K_{\mathrm{Na}} \\
(\mathrm{mmol} / \mathrm{l})\end{array}$ & $n$ \\
\hline $\begin{array}{l}\text { Proximal colon: } \\
\quad \text { Control rats }(\mathrm{n}=5)\end{array}$ & $59(150)$ & $18(4)$ & $1 \cdot 7(0 \cdot 2)$ \\
$\quad \begin{array}{l}\text { Dexamethasone treated rats }(\mathrm{n}=7) \\
\mathrm{p}^{\star \star}\end{array}$ & $81(10)$ & $13(2)$ & $2 \cdot 2(0 \cdot 2)$ \\
Distal colon: & $\mathrm{NS}$ & $\mathrm{NS}$ & $\mathrm{NS}$ \\
$\quad$ Control rats $(\mathrm{n}=6)$ & $70(12)$ & $11(1)$ & $2 \cdot 4(0 \cdot 3)$ \\
$\quad$ Dexamethasone treated rats $(\mathrm{n}=8)$ & $211(49)$ & $14(1)$ & $2 \cdot 3(0 \cdot 3)$ \\
$\mathrm{p}^{\star \star}$ & $<0 \cdot 05$ & $\mathrm{NS}$ & $\mathrm{NS}$ \\
\hline
\end{tabular}

Isc, $\max =$ the apparent maximum short circuit current; $\mathrm{K}_{\mathrm{N}_{\mathrm{a}}}=\mathrm{Na}^{+}$concentration at which slope of Isc on $\mathrm{Na}^{+}$concentration is maximal; $n$ (Hill coefficient) $=$ the minimum number of $\mathrm{Na}^{+}$ions binding to each $\mathrm{Na}^{+}-\mathrm{K}^{+}$pump site; $n=$ number of tissues studied.

$\star \star=$ difference between control and dexamethasone treated tissues.

significantly $(\mathrm{p}<0.05)$ by dexamethasone treatment, although $\mathrm{K}_{\mathrm{Na}}$ and $n$ were unchanged.

\section{Discussion}

The results of this study indicate that rat colon exhibits appreciable segmental differences in $\mathrm{Na}^{+}$and $\mathrm{K}^{+}$transport in response to pharmacological doses of dexamethasone. In the distal colonic segment, dexamethasone induced or activated relatively large apical conductances for $\mathrm{Na}^{+}$ and $\mathrm{K}^{+}$and increased the maximum activity of the basolateral $\mathrm{Na}^{+}-\mathrm{K}^{+}$pump by $200 \%$, an effect that has been shown to reflect increases in the area of the basolateral membrane and its number of $\mathrm{Na}^{+}-\mathrm{K}^{+}$pump units. ${ }^{16}$ Thus dexamethasone induced a substantial amount of electrogenic $\mathrm{Na}^{+}$ absorption, and altered the $\mathrm{K}^{+}$transport properties of the epithelium so as to favour enhanced $\mathrm{K}^{+}$ movement from plasma to lumen via transcellular and paracellular pathways. Although dexamethasone has by tradition been regarded as a glucocorticoid agonist, at high doses it produces $>80 \%$ occupancy of mineralocorticoid receptors in addition to activating glucocorticoid receptors. ${ }^{8}$ Indeed, it is likely that stimulation of distal colonic $\mathrm{Na}^{+}$and $\mathrm{K}^{+}$transport by dexamethasone mainly reflects activation of mineralocorticoid receptors, as the electrical changes induced by high doses of dexamethasone resemble those induced by aldosterone rather than those induced by similar high doses of RU 28362, a specific glucocorticoid agonist for which mineralocorticoid receptors have negligible affinity. ${ }^{10}$

Although the effects of chronic dexamethasone administration on $\mathrm{Na}^{+}$and $\mathrm{K}^{+}$transport across rat distal colon have been described previously, ${ }^{910}$ the present study indicates that the proximal colon responded quite differently to a combination of mineralocorticoid and glucocorticoid receptor activation by dexamethasone. Compared with control animals, dexamethasone induced an appreciable increase in $G_{1}$ in the proximal colon, but the associated increase in Isc was less than that induced in the distal colon (58 $\mu \mathrm{A} / \mathrm{cm}^{2}$ versus $566 \mu \mathrm{A} / \mathrm{cm}^{2}$, Table I). The insensitivity of dexamethasone treated proximal colon to amiloride and TEA (Fig l) suggests that the dexamethasone induced increases in $G_{1}$ and Isc observed in this segment reflected stimulation of an electrogenic ion transport process(es) other than electrogenic $\mathrm{Na}^{+}$absorption (or electrogenic $\mathrm{K}^{+}$secretion). The inability of dexamethasone to enhance basolateral $\mathrm{Na}^{+}-\mathrm{K}^{+}$pump activity in the proximal colon is also consistent with the glucocorticoid's lack of effect on electrogenic cation transport in this segment. This notion is supported by other studies in rat proximal colon, which have shown that mineralocorticoid receptor activation by aldosterone stimulates electroneutral $\mathrm{Na}-\mathrm{Cl}$ (not electrogenic $\mathrm{Na}^{+}$) absorption, ${ }^{17}{ }^{18}$ and an active $\mathrm{K}^{+}$secretory process which is less noticeable than that stimulated in rat distal colon. ${ }^{18} 19$ In contrast, the specific glucocorticoid receptor agonist RU 28362 (which also stimulates electroneutral $\mathrm{Na}-\mathrm{Cl}$ absorption) has no effect on net $\mathrm{K}^{+}$secretion. ${ }^{18}$ Thus, the results of the present and these other studies suggest that dexamethasone activated both mineralocorticoid and glucocorticoid receptors in rat proximal colon, resulting in the stimulation of electroneutral $\mathrm{Na}-\mathrm{Cl}$ absorption and a small $\mathrm{K}^{+}$secretory response which could not be detected by electrical measurements alone.

The present study also indicates that the $\mathrm{Cl}$ channel blocker DPC abolished the high amiloride insensitive Isc $\left(139(16) \mu \mathrm{A} / \mathrm{cm}^{2}\right)$ in dexamethasone treated proximal colon, but did not change the low amiloride-insensitive Isc ( 30 (6) $\mu \mathrm{A} / \mathrm{cm}^{2}$ ) in dexamethasone treated distal colon. This segmental difference suggests that dexamethasone induced a significant electrogenic $\mathrm{Cl}^{-}$secretory process which was limited to the proximal colon. It should be noted that high doses of the glucocorticoid methylprednisolone also stimulate $\mathrm{Cl}^{-}$secretion in rat distal ileum ${ }^{20}$ and $\mathrm{HCO}_{3}{ }^{-}$secretion in rabbit distal ileum. ${ }^{21}$ Although $\mathrm{Cl}^{-}$and $\mathrm{HCO}_{3}^{-}$(residual) fluxes were not measured here, it is possible that the dexamethasone induced, DPC sensitive apical $\mathrm{Cl}$ conductance in proximal colon also had a degree of selectivity for $\mathrm{HCO}_{3}$.

The spectrum of $\mathrm{Na}^{+}$transport processes present in rat colon differs from that in human colon. The predominant $\mathrm{Na}^{+}$transport processes in rat colon are electroneutral $\mathrm{Na}^{+}-\mathrm{H}^{+}$exchange in the proximal segment ${ }^{17}$ and electroneutral $\mathrm{Na}$ $\mathrm{Cl}$ absorption in the distal segment. ${ }^{92}$ In contrast, there is appreciable electroneutral $\mathrm{Na}-\mathrm{Cl}$ absorption in the proximal (ascending), transverse, and distal (descending) segments of human colon. ${ }^{2324}$ In addition, electrogenic $\mathrm{Na}^{+}$ absorption is present throughout human colon, although this process only becomes noticeably amiloride sensitive distal to the splenic flexure. ${ }^{725}$ Despite these segmental and species differences in baseline $\mathrm{Na}^{+}$transport mechanisms, there is evidence that suggests that similar changes in colonic $\mathrm{Na}^{+}$transport may be induced in rat and human colon by glucocorticoid agonists that activate both glucocorticoid and mineralocorticoid receptors - for example dexamethasone, and methylprednisolone and hydrocortisone, both of which are used commonly in the treatment of inflammatory bowel disease. Thus, in rat proximal colon, glucocorticoid and mineralocorticoid receptor activation stimulates electroneutral $\mathrm{Na}-\mathrm{Cl}$ absorption without the appearance of amiloride sensitive electrogenic $\mathrm{Na}^{+}$absorption. ${ }^{18}$ It seems likely that a similar response may occur in human proximal colon, which is normally characterised by electroneutral $\mathrm{Na}-\mathrm{Cl}$ absorption $^{2324}$ and where purely mineralocorticoid receptor activation by aldosterone fails 
to induce amiloride sensitive electrogenic $\mathrm{Na}^{+}$ absorption. ${ }^{7}$ In contrast, in rat distal colon and human distal colon and rectum, glucocorticoid agonists - for example dexamethasone, methylprednisolone, hydrocortisone - stimulate amiloride sensitive electrogenic $\mathrm{Na}^{+}$absorption via mineralocorticoid receptors ${ }^{410}$ and may also enhance electroneutral $\mathrm{Na}-\mathrm{Cl}$ absorption via glucocorticoid receptors. ${ }^{19}$

In summary, it seems likely that systemically administered glucocorticoids reduce diarrhoea in active colitis by exerting direct effects on $\mathrm{Na}^{+}$ (and hence water) absorption throughout the colon, as well as by their better recognised antiinflammatory action. Glucocorticoids may stimulate $\mathrm{Na}^{+}$absorption in normal and inflamed distal colon and rectum ${ }^{4}$ through a combination of glucocorticoid receptor activation (enhancing electroneutral $\mathrm{Na}-\mathrm{Cl}$ absorption) and crossover binding to mineralocorticoid receptors (enhancing electrogenic $\mathrm{Na}^{+}$absorption). In human proximal colon, glucocorticoids may only stimulate electroneutral $\mathrm{Na}-\mathrm{Cl}$ absorption, despite binding to both types of corticosteroid receptor.

Dr Sandle was a Medical Research Council Senior Clinical Fellow.

1 Truelove S, Witts LJ. Cortisone and corticotrophin in ulcer tive colitis. BMF 1959; i: 387-94

2 Summers RW, Switz DM, Sessions JT, et al. National Cooperative Crohn's Disease Study: results of drug treatment. Gastroenterology 1979; 77: 847-69.

3 Malchow H, Ewe K, Brandes JW, et al. European Cooperative Crohn's Disease Study (ECCDS): results of drug treatment. Crohn's Disease Study (ECCDS):

4 Sandle GI, Hayslett JP, Binder HJ. Effect of glucocorticoids on rectal transport in normal subjects and patients with on rectal transport in normal subjects

5 Hawker PC, Mashiter KE, Turnberg LA. Mechanisms of transport of $\mathrm{Na}, \mathrm{Cl}$ and $\mathrm{K}$ in the human colon. Gastroenterology 1978; 74: 1241-7.

6 Wills NK, Alles WP, Sandle GI, Binder HJ. Apical membrane properties and amiloride binding kinetics of the human descending colon. Am 7 Physiol 1984; 247: G749-57.
7 Sandle GI. Segmental heterogeneity of basal and aldosteroneinduced electrogenic $\mathrm{Na}$ transport in human colon. Pfluger Arch 1989; 414: 706-12.

8 Bastl CP. Regulation of cation transport by low doses of glucocorticoids in in vivo adrenalectomized rat colon. $7 \mathrm{Clin}$ Invest 1987; 80: 348-56

9 Foster ES, Zimmerman TW, Hayslett JP, Binder HJ. Corticosteroid alteration of active electrolyte transport in rat distal colon. Am F Physiol 1983; 245: G668-75.

10 Binder HJ, McGlone F, Sandle GI. Effects of corticosteroid hormones on the electrophysiology of rat distal colon: implications for $\mathrm{Na}^{+}$and $\mathrm{K}^{\prime}$ transport. $\mathcal{F}$ Physiol $1989 ; 410$. implication-41.

11 Lewis SA, Eaton DC, Diamond JM. Nystatin as a probe for investigating the electrical properties of a tight epithelium. $\mathcal{J}$ Gen Physiol 1977; 70: 427-40.

12 Wills NK, Lewis SA, Eaton DC. Active and passive propertie of rabbit descending colon. A microelectrode and nystatin study. F Membr Biol 1979; 45: 81-108.

13 Cass A, Finkelstein A, Krespi V. The ion permeability induced in thin lipid membranes by polyene antibiotics nystatin and amphotericin. F Gen Physiol 1970; 50: 100-24.

14 Nelson MT, Blaustein MP. Properties of sodium pumps in internally perfused barnacle muscle fibres. 7 Gen Physiol 1980; 75: 183-206.

15 Sandle GI, McGlone F. Segmental variability of membrane conductances in rat and human colon epithelia. Implications

16 Kashgarian M, Taylor CR, Binder HJ, Hayslett JP. Amplification of cell membrane surface in potassium adaptation. $\mathrm{Lab}$ Invest 1980; 42: 581-8.

17 Foster ES, Budinger ME, Hayslett JP, Binder HJ. Ion transport in proximal colon of the rat. Sodium depletion stimulates neutral sodium chloride absorption. $f$ Clin Invest 1986; 77: 228-35.

18 Turnamian SG, Binder HJ. Aldosterone and glucocorticoidspecific agonists regulate ion transport in rat proximal colon. Am $\mathcal{F}$ Physiol 1990; 258: G492-98.

19 Turnamian SG, Binder HJ. Regulation of active sodium and potassium transport in the distal colon of the rat. Role of the potassium transport in the distal colon of the rat. Role of the aldosterone

20 Yuan-Heng T, Decker RA, Marnane WG, Charney AN, Donowitz $M$. Effects of methylprednisolone on electrolyte transport by in vitro rat ileum. Am F Physiol 1981; 240. G365-70.

21 Sellin JH, Field M. Physiologic and pharmacologic effects of glucocorticoids on ion transport across rabbit ileal mucosa in vitro. $\mathcal{F}$ Clin Invest 1981; 67: 770-8.

22 Halevy J, Budinger ME, Hayslett JP, Binder HJ, Role of aldosterone in the regulation of sodium and chloride transport in the distal colon of sodium-depleted rats. Gastroenport in the distal colon of

23 Hubel KA, Renquist K, Shirazi S. Ion transport in human cecum, transverse colon, and sigmoid colon in vitro. Basececum, transverse colon, and sigmoid colon in vitro. Base-
line and response to electrical stimulation of intrinsic nerves. Gastroenterology 1987; 92: 501-7.

24 Sellin JH, DeSoignie R. Ion transport in human colon in vitro. Gastroenterology 1987; 93: 441-8.

25 Sandle GI, Wills NK, Alles W, Binder HJ. Electrophysiology of the human colon: evidence of segmental heterogeneity Gut 1986; 27: 999-1005. 